\title{
O małżeńskich darowiznach na wypadek śmierci w XVIII w. w świetle akt Metryki Koronnej
}

\section{WPROWADZENIE}

W wyniku zachodzących od schyłku średniowiecza zmian zmierzających do wzmocnienia pozycji majątkowej małżonka w XVII-XVIII w. szerokie zastosowanie w prawie ziemskim znalazły umowy dożywocia. Badania źródłowe jednak wskazują, że szlachcie znana była także instytucja małżeńskiej darowizny na wypadek śmierci. Chociaż umowy takie zawierano zdecydowanie rzadziej, to wypracowanie dla nich $\mathrm{w}$ drodze zwyczaju jednolitego formularza świadczy o społecznym zainteresowaniu nimi.

Przyjęta w polskim prawie ziemskim zasada rozdzielności majątkowej małżonków, wykluczająca żonę lub męża ze schedy po zmarłym współmałżonku, nie była w praktyce przestrzegana. Zawarty w Statutach Kazimierza Wielkiego zakaz obejmowania przez żonę w zarząd całego majątku po śmierci męża (Statut nakazywał wdowie pozostawanie wyłącznie na dobrach posagowych i oprawnych, tj. na tzw. wdowim stolcu, z zachowaniem majątku otrzymanego w formie wyprawy) ${ }^{1}$, z pokrzywdzeniem jego spadkobierców, dowodzi, że zjawisko to co najmniej do połowy XIV w. musiało mieć charakter powszechny². Co więcej, wspomniana

${ }^{1}$ Art. CI, „Statuimus quod marito mortuo uxor circa donationem et dotem et quaelibet paraphernalia in pecuniis, gemmis, lapidibus et vestibus superextantibus debeat remanere", Starodawne prawa polskiego pomniki, t. I, wyd. A. Helcel, Warszawa 1856, s. 121; por. Statuty Kazimierza Wielkiego, wyd. O. Balzer, Poznań 1947, art. XCVIII, s. 509-510; Kodeks Stronczyńskiego II, art. 95 [w:] Archiwum Komisji Prawniczej, t. IV, Kraków 1921, s. 669; Kodeks Ossolińskich II, art. 100 [w:] Archiwum Komisji Prawniczej, t. IV, Kraków 1921, s. 382.

2 S. Roman, Stanowisko majątkowe wdowy w średniowiecznym prawie polskim, „Czasopismo Prawno-Historyczne" [dalej: CPH] 1953, t. V, s. 81. 
praktyka, mimo jej zdecydowanej krytyki (zwyczaj określano mianem szkodliwego - damnosa consuetudo), nie ustała, czego konsekwencją było ponowienie zakazu w wydanym w 1423 r. przez Władysława Jagiełłę statucie warckim³ . W rezultacie popularność wśród szlachty, wciąż szukającej możliwości zabezpieczenia majątkowego współmałżonka na wypadek śmierci, zyskały zapisy dożywocia ${ }^{4}$ (advitalitas inter coniuges; inscriptiones inter coniuges ad tempora vitae), których stosowanie usankcjonowano w 1523 r., umieszczając w Formula processus ich wzorzec $^{5}$, na podstawie którego takie zapisy sporządzano. W większości przypadków miały one charakter wzajemny ${ }^{6}$, zrównując obie strony i gwarantując prawo do użytkowania majątku tej, która przeżyła małżonka, bez względu na to, czy był to mężczyzna, czy kobieta. Zapisy dożywocia nie skutkowały jednak przeniesieniem własności dóbr na żonę (męża), a jedynie uprawniały wdowę (wdowca) do dożywotniego ich używania i pobierania pożytków bez prawa do alienacji. Prawa spadkobierców do nabycia spadku ulegały zawieszeniu na czas życia dożywotnika. Dopiero po jego śmierci majątek przekazywany był sukcesorom zmarłego wcześniej małżonka. Umowy dożywocia jako wyraz zgodnego oświadczenia woli męża i żony, których głównym celem było zapewnienie małżonkowi prawa do użytkowania majątku, często wspólnie wypracowanego w okresie małżeństwa, pozwalały zachować dobra w ręku jednej ze stron, bez równoczesnego wykluczania ze spadkobrania dziedziców koniecznych, a jedynie odsuwając ich prawo do sukcesji w czasie. Mimo zalet takiego rozwiązania dożywotnik pozbawiony był, pod groźbą utraty dożywocia, prawa do dokonywania na dobrach nim objętych jakichkolwiek czynności o charakterze rozporządzającym: zbycia, zastawienia, a nawet wydzierżawiania ${ }^{7}$. W konsekwencji dobra dożywotnie w stanie nienaru-

\footnotetext{
${ }^{3}$ Ibidem. Zob. Starodawne prawa..., t. I, s. 307-308: Art. II, „Ad abolendam [...] statuimus quod uxor marito mortuo, tantum circa dotem et dotalitium remaneat, alia vero, in quibus dotem seu dotalitium non habuerit, pueris vel proximioribus teneatur resignare". Jak sugeruje P. Dąbkowski, podobna uchwała zapadła na zjeździe w Wiślicy w 1434 r. Zob. P. Dąbkowski, Prawo prywatne polskie, t. I, Lwów 1910, s. 421.

${ }^{4} \mathrm{Na}$ genezę umów dożywocia zwrócił uwagę S. Roman, Stanowisko majątkowe wdowy..., s. 97, a także W. Uruszczak w recenzji pracy M. Koczerskiej (Rodzina szlachecka w Polsce późnego średniowiecza, Warszawa 1975), Uwagi o polskiej rodzinie szlacheckiej w późnym średniowieczu, CPH 1976, t. XXVIII, z. 2, s. 259.

5 Volumina Constitutionum [dalej: VC], t. I (1493-1549), vol. I (1493-1526), wyd. S. Grodziski, I. Dwornicka, W. Uruszczak, Warszawa 1996, s. 403. Por. Volumina Legum. Przedruk zbioru praw staraniem XX. Pijarów w Warszawie od roku 1732 do roku 1782 wydanego [dalej: VL], t. I, wyd. J. Ohryzko, Petersburg 1859, fol. 419-420.

${ }^{6}$ Znamy jednak szereg przypadków jednostronnych zapisów dożywocia. Zob. M. Głuszak, Advitalitas simplex $i$ advitalitas mutua w polskim prawie ziemskim, „Krakowskie Studia z Historii Państwa i Prawa” 2018, t. 11, z. 2, s. 219-220.

7 ,Si damnum in bonis notabile faceret, vel si ius suum in alium transfunderet, vel illa bona obligaret, vel arendaret [...] advitalitatem suum violat et per consequens perdit successoribusque ad
} 
szonym powinny były wrócić do spadkobierców zapisodawcy. Oznaczało to, że nieposiadający żadnych praw do dóbr objętych dożywociem najbliżsi krewni dożywotnika (np. syn wdowy, będący zarazem pasierbem zmarłego współmałżonka, pomagający jej w zarządzaniu dobrami) byli zobowiązani po jego śmierci bez jakichkolwiek przeszkód przekazać te dobra (jeśli faktycznie w nich pozostawali) rodzinie zmarłego wcześniej małżonka ${ }^{8}$.

Problemu nie rozwiązywało sporządzenie testamentu - kolejne konstytucje sejmowe z 1505 i 1510 r. zakazywały w jego ramach rozporządzania nieruchomościami .

Dobrym rozwiązaniem mogło być natomiast zawarcie umowy darowizny. Jednak i tu natrafiano na istotne utrudnienia. W szczególności sporządzanie darowizny przez żonę na rzecz męża jeszcze w późnym średniowieczu, dopuszczane zarówno aktem między żyjącymi, jak i na wypadek śmierci ${ }^{10}$, było stopniowo ograniczane $^{11}$. Wreszcie na sejmie radomskim w 1505 r. uchwalono konstytucję De inscriptione uxoris stanowiącą: „Item uxor marioto suo nihil inscribat sine consensu amicorum, etsi inscribit illud nullius roboris sit" "12, a więc uzależniającą ważność takiej czynności od zgody krewnych kobiety ${ }^{13}$.

Jak na tę kwestię zapatrywali się autorzy kompendiów prawniczych okresu I Rzeczypospolitej?

bona recuperanda late patet via". T. Zawadzki, Processus iudiciarius Regni Poloniae, Warszawa 1647, s. 54. Kwestia prawa do wydzierżawiania majątku dożywotniego budzi wątpliwości. Zdaniem P. Burzyńskiego (Prawo polskie prywatne, t. II, Kraków 1871, s. 155) i S. Płazy (Historia prawa $w$ Polsce..., cz. I, s. 246) było ono dozwolone.

${ }^{8}$, „Bona praefata [...] ad successores praedicti $N$. devolventur sine quovis impedimento et contradictione successorum praefatae N.", VC, t. I, vol. 1, s. 403.

9 „Testamenta super bonis immobilibus facta, nullius sunt roboris, nullaque reputentur”, VC, t. I, vol. 1, s. 144 (Konstytucja De testamentis in bonis immobilibus et in bonis regalibus factis wchodząca w skład Constitutiones temporales Radomiensis conventionis generalis proxime praeteritae została pominięta w zbiorze VL); „Decernimus, ut testamenta condantur iuxta veterem constitutionem, ex more antiquitus servatam, de bonis mobilibus. Immobilia autem bona, tam haereditaria quam oppignorata, de defensio reipublicae minuatur, testamentali ordinationi minime subiecta esse debent", VC, t. I, vol. 1, s. 227. Por. VL, t. I, fol. 369.

10 A. Winiarz, Polskie prawo majątkowe matżeńskie w wiekach średnich, Kraków 1898, s. 64.

${ }_{11}$ P. Dąbkowski, Prawo prywatne..., t. I, s. 419.

12 VC, t. I, vol. 1, s. 157.

${ }^{13}$ Podobnie prawo mazowieckie skodyfikowane w Zwodzie Goryńskiego stanowiło: „Uxor bona sua propria non potest de jure resignare perpetualiter marito suo absque consensu et scientia amicorum consanguineorum suorum quorumqunque", Statuta Ducatus Mazoviae [w:] Jus Polonicum codicibus veteribus manuscriptis et editionibus quibusque collatis, wyd. J.W. Bandkie Stężyński, Warszawa 1831, s. 381. Natomiast jak podaje K. Dunin, już w XIII w. mężowi przysługiwało prawo obdarowania żony, zarówno za życia, jak i na wypadek śmierci. K. Dunin, Dawne mazowieckie prawo, Warszawa 1880, s. 131. 
Sporządzanie darowizn dóbr nieruchomych na wypadek śmierci było niedopuszczalne zdaniem Teodora Ostrowskiego, który za Teodorem Zawadzkim powtórzył, że donacja takich dóbr mortis causa albo na przeżycie równałaby się zapisowi testamentowemu, ,a pod te dobra ziemskie albo nieruchome nie podpadają"14.

Mikołaj Zalaszowski, odwołując się do prawa rzymskiego, stwierdził natomiast, że choć umowa darowizny jednostronnej (donatio simplex) zawarta między małżonkami była zabroniona (wymienia jednak za prawem saskim szereg wyjątków od tej reguły, np. darowizna starego męża na rzecz młodej żony), to - jak pisze dalej - „Tamen si coniuges faciant invicem donationem reciprocam, si contingat alterum praemori, non dicitur donatio de jure civili prohibita, sed valebit non indigebit confirmatione per mortem, etiam non interveniente traditione, quod tamen alias requiritur et sic post mortem donantis, poterunt bona donata, etiam prius non tradita peti ${ }^{\prime 15}$. Jurysta dopuszczał zatem darowiznę małżeńską wzajemną na wypadek śmierci ${ }^{16}$.

Warto dodać, że kwestii darowizny między małżonkami nie regulował w jednoznaczny sposób projekt Zbioru Praw Sądowych [dalej: ZPS] Andrzeja Zamoyskiego, ograniczając się wyłącznie do instytucji dożywocia małżeńskiego. Owszem, w myśl $\S 8$ art. XV „O donacjach” cz. II ZPS osobom bezdzietnym wolno było bez ograniczeń co do kręgu beneficjentów przekazywać w darowiźnie nieruchomości nabyte, z zastrzeżeniem, że dobra dziedziczne mogą zostać przez takie osoby darowane wyłącznie najbliższym krewnym. Podobnie $\S 9$ zezwalał na dokonanie darowizny dóbr nieruchomych, ale tylko „dorobnych”, bezdzietnej $\dot{z ̇ o n i e}^{17}$. Czy można było zatem dokonać takiego zapisu na rzecz współmałżonka? Brak na ten temat informacji w art. XXI „O sukcesji między małżeństwem”. Wątpliwości odnośnie do regulacji ZPS w części poświęconej zapisom testamentowym i darowiznom między małżonkami przedstawił zresztą Walenty Dutkiewicz, pisząc: „czy wolno było rozporządzać [nieruchomościami - M.G.] na korzyść małżonka? - nic stanowcza redakcja nie rozstrzyga" ${ }^{18}$.

${ }^{14}$ T. Ostrowski, Prawo cywilne albo szczególne narodu polskiego, t. I, Warszawa 1784, s. 143144. Podobnie J.W. Bandtkie Stężyński podkreślił, że prawu polskiemu nieznana była forma donationes mortis causae. J.W. Bandtkie Stężyński, Prawo prywatne polskie napisane i wykładane przed rokiem 1830, Warszawa 1851, s. 376.

15 M. Zalaszowski, Ius Regni Poloniae, t. II, Poznań 1702, s. 172-173.

${ }^{16}$ I. Malinowska, Mikołaj Zalaszowski. Polski prawnik XVII stulecia na tle ówczesnej nauki prawa, Kraków 1960, s. 174.

17 Zbiór Praw Sąowych Na Mocy Konstytucyi Roku 1776 przez J.W. Andrzeja Zamoyskiego, Ex-Kanclerza Koronnego, Kawalera Orderu Orła Białego, ułożony y na Seym Roku 1778 podany, Warszawa 1778.

${ }_{18}$ W. Dutkiewicz, Zbiór Praw Sądowych przez ex-kanclerza Andrzeja Ordynata Zamojskiego ułożony i w roku 1778 drukiem ogłoszony, Warszawa 1874, s. 389. 
Wobec tak restrykcyjnego w tym zakresie prawa ziemskiego ciekawe rozwiązanie oferowało prawo chełmińskie. Rewizja nowomiejska z 1580 r., z której korzystały nie tylko miasta Prus Królewskich i Mazowsza, ale również posiłkowo miejscowa szlachta (prawo chełmińskie już w XV w., po uchyleniu prawa magdeburskiego, staropruskiego i polskiego stało się prawem wszechstanowym) ${ }^{19}$, stanowiła: „Stosownie do naszego prawa, którego przestrzegamy, mąż żonie i wzajemnie żona mężowi zarówno na zasadzie dziedzicznego prawa własności, jak na zasadzie prawa dożywotniego użytkowania mogą darować dobra, a mianowicie na mocy prawa spadkowego w ten sposób, aby pozostały przy życiu małżonek wypłacił spadkobiercom zmarłego pewną kwotę pieniędzy, określoną przy dokonaniu cesji dóbr" ${ }^{20}$. Artykuł ten dopuszczał zatem nie tylko możliwość sporządzenia znanego prawu ziemskiemu zapisu dożywocia, ale również przekazanie małżonkowi majątku w formie darowizny, dzięki której po śmierci darczyńcy obdarowana strona nabywała pełne prawo do rzeczy, a więc również przekazania jej w drodze dziedziczenia swoim spadkobiercom. Jedynym warunkiem było spłacenie spadkobierców darczyńcy. Umowa ta określana była w księgach kancelaryjnych jako donatio reciproca.

\section{PRAKTYKA SPORZĄDZANIA DAROWIZNY MAŁŻEŃSKIEJ NA WYPADEK ŚMIERCI}

\section{Analizowany material źródłowy}

Materiałem źródłowym, który poddano analizie pod kątem badań nad darowiznami małżeńskimi, były akta Metryki Koronnej z lat 1700-1794. Istotne znaczenie ma tu specyfika źródła. Od lat 60. XVI w. w księdze wpisów Metryki stopniowo pojawiają się akty o charakterze prywatnoprawnym ${ }^{21}$, a swoje zeznania zaczęli w niej umieszczać reprezentanci szlachty. Odtąd w Metryce znaleźć można szeroki wachlarz transakcji i zeznań osób prywatnych. Jednocześnie akta

19 Z. Zdrójkowski, Zarys dziejów prawa chetmińskiego 1233-1862, Toruń 1983, s. 29; Z. Kaczmarczyk, Historia państwa i prawa Polski, t. II, red. J. Bardach, Warszawa 1968, s. 272.

${ }^{20}$ Ks. III, art. CXXVI. 28, Rewizja nowomiejska prawa chetmińskiego 1580 (1814) zwana także Jus culmense emandatum lub Jus culmense polonicum, przekład I. Malinowska-Kwiatkowska, J. Sondel, przekład zweryfikował Z. Rymaszewski, Toruń 1993, s. 87; P. Kuszewic, Ks. III, art. XXVIII, Prawa chetmienskiego poprawionego i z łacińskiego języka na polski przettumaczonego ksiag pięcioro, Poznań 1697, s. 71. Por. Jus culmense, cum appendice privilegiorum et jurium selectorum municipalium, et dissertatione historicojuridica, exhibitum cura Joannis Vincentii Bandtkii, wyd. J.W. Bandkie Stężyński, Warszawa 1814, s. 139.

${ }^{21}$ I. Sułkowska-Kurasiowa, Księgi wpisów Metryki Koronnej (1447-1795) w Archiwum Głównym Akt Dawnych w Warszawie, „Archeion” 1966, t. XLIV, s. 87. 
te cechuje szczególny, uniwersalny charakter - wpisów do Metryki dokonywali nie tylko mieszkańcy Warszawy i Mazowsza, ale również szlachta ${ }^{22}$ obu prowincji koronnych, a nawet Wielkiego Księstwa Litewskiego.

\section{Darowizny wzajemne - donatio reciproca}

Najczęściej zawieraną umową darowizny małżeńskiej na wypadek śmierci była darowizna wzajemna ${ }^{23}$. Odnotowano 15 takich aktów. Były one rejestrowane w księgach inskrypcji Metryki Koronnej pod tytułem „Inscribunt sibi donationem reciprocam (omnium et singulorum bonorum suorum) ${ }^{24}$ Generosi $X$ ab invincem conjuges” lub „Oblata donationis reciproca per Generosi X”. Przy sporządzaniu umów korzystano z gotowych formularzy, które były takie same dla wszystkich zeznających (nie licząc drobnych różnic stylistycznych, które mogły wynikać ze zmian, jakim tekst ulegał $\mathrm{w}$ trakcie przepisywania), niezależnie od miejsca ich osiadłości. Może na to wskazywać jednolity łaciński tekst aktów (dopiero w ostatnich latach Rzeczypospolitej znajdujemy pojedyncze dokumenty w języku polskim $^{25}$ ). We właściwym miejscu wstawiano jedynie zmienne dane, jak imiona, nazwiska, kwoty. Wspólny dla wszystkich badanych umów układ wewnętrzny pozwala wskazać charakterystyczne cechy takich darowizn ${ }^{26}$.

${ }^{22} \mathrm{Na}$ stan szlachecki małżonków podpisujących umowy darowizny wskazują określenia: generosus, -a, nobilis, nobilis ac spectabilis, ,wielmożny, -a”, „urodzony, -a”.

${ }^{23}$ Pojęcie darowizny wzajemnej znane jest literaturze. Termin ten odnosił się jednak do różnych instytucji. I tak, darowiźnie wzajemnej poświęca jeden z rozdziałów swojej monografii J. Bardach, mając na uwadze tzw. darowiznę remuneratoryjną, a więc odpłatną, zbliżoną w swoim charakterze do umowy kupna-sprzedaży lub polegającą na odwzajemnieniu daru przez wykonanie określonej usługi, opieki. Zob. Studia z ustroju i prawa Wielkiego Księstwa Litewskiego XIV-XVII w., Warszawa 1970, s. 174-187. Podobnie darowiznę wzajemną definiuje S. Płaza, Historia prawa w Polsce na tle porównawczym, cz. I, Kraków 2002, s. 320. O darowiźnie wzajemnej między małżonkami pisano stosunkowo niewiele. Głównie w odniesieniu do prawa miejskiego wspominają o niej: W. Spasowicz, O stosunkach majątkowych między matżonkami wedle dawnego prawa polskiego [w:] Pisma, t. IV, Petersburg 1892, s. 36; S. Ehrenkreutz, O stosunkach majątkowych między matżonkami wedlug prawa chetmińskiego w Warszawie w wieku XVII, Warszawa 1915, s. 11, 13.

${ }^{24}$ Sformułowanie pojawia się w niektórych aktach.

${ }^{25} \mathrm{~W}$ przypadku grodów do 1792 r. zeznania wpisywane były po łacinie, tj. w języku urzędowym sądów. W latach późniejszych w przypadku oblat w języku urzędowym wypisywano tylko formuły początkowe i końcowe, sam akt oblatowany był w języku polskim. Zob. S. Kutrzeba, Historia źródet dawnego prawa polskiego, t. I, Kraków 1925, s. 141. Podobne rozwiązania spotykamy w Metryce Koronnej.

${ }^{26}$ Więcej o formularzach wykorzystywanych w kancelariach sądowych okresu I Rzeczypospolitej zob. O. Balzer, Kancelarie i akta grodzkie w wieku XVIII, Lwów 1882, s. 21; J. Bielecka, Organizacja i działalność kancelarii ziemskich i grodzkich wielkopolskich XVI-XVIII w., „Archeion” 1954, t. XXII, s. 149-150; W. Witkowski, XVIII-wieczny zbiór formuł prawnych grodu lubelskiego, „Rocznik Lubelski” 1973, t. 16, s. 143-145. Formularza umowy donatio reciproca nie podają jednak w swoich dziełach autorzy największych kompendiów prawniczych tego okresu, w których 


\subsection{Klauzule wstępne}

$\mathrm{Na}$ wstępie aktu, po stałej formule zawierającej informację o osobistym stawiennictwie (comparentes personaliter) i zdolności do złożenia zeznania (sani mente et corpore existentes), małżonkowie składali oświadczenie o rezygnacji, czyli odstąpieniu od właściwej dla nich jurysdykcji ziemskiej na rzecz Metryki Koronnej ${ }^{27}$. Była to praktyka dość powszechna. Część zeznań miała charakter pierwotny, w pozostałych przypadkach oblatowano umowy zawarte i zarejestrowane już wcześniej w aktach grodzkich lub ziemskich ${ }^{28}$. Inskrypcja do Metryki Koronnej była zapewne dodatkowym zabezpieczeniem umowy na wypadek próby podważenia jej mocy przez osoby trzecie lub zniszczenia akt miejscowych.

\subsection{Asystencja dla kobiety}

$\mathrm{Z}$ uwagi na alienacyjny charakter umowy zgodnie z obowiązującym prawem kobieta zobowiązana była do złożenia oświadczenia woli w asystencji mężczyzny ${ }^{29}$. Ponieważ nie mógł być nim w tym przypadku mąż (ewentualny beneficjent umowy), mógł jej towarzyszyć krewny ${ }^{30}$. Ponadto w aktach Metryki Koronnej

zebrano blisko 150 różnego typu wzorców. Zob. M. Słoński, Accessoria, statut i konstytucye Czaradzkiego, Ładowskiego y suplementu J.O. Xcia Jegomości Biskupa Krakowskiego w Pospolitości a najbardziej co do procesu potrzebniejszego tudzież Formularze tranzakcyi niektórych przez Jmci Pana Michała Stońskiego Vicegerenta Łukowskiego S.G. zebrane, Lwów 1765; T. Ostrowski, Prawo cywilne..., t. II; S. Zagórski, Formulae juridicae inducendis et conficiendis transactionibus accomodatae legibus Regni conformes ac in castro Lublinensi usitate cura et impensis Simonis Zagorski Vice Regentis castrensis Lublinensis luci publicae traditae. Cum facultate superiorum. Lublini typis S.R.M. Collegii Societatis Jesu, Lublin 1768.

${ }^{27}$ „A foro, terris, districtibus et jurisdictione sua quavis propria et competenti recedendo praesenti vero Nostra Regia se cum bonis suis generaliter omnibus subjiciendo et incorporando sponte, palam, libere ac per expressum recognoverunt, praesentibusque recognoscunt". Zob. przykładowo AGAD [w kolejnych przypisach, w których powoływane jest źródło Metryki Koronnej, zrezygnowano ze skrótu AGAD], Metryka Koronna [dalej: MK], sygn. 265, k. 213.

${ }^{28}$ Małżonkowie Robert i Anna Barbara Farcher podpisali umowę darowizny wzajemnej w Krakowie w 1748 r., w Metryce Koronnej akt ten oblatowano cztery lata później, MK 229, k. 826.

${ }^{29}$ Zwyczaj asystowania kobiecie przez męża w czynnościach dokonywanych przed sądem był rozumiany dwojako, jako przysługujący żonie przywilej lub ograniczenie jej praw procesowych. Jak wskazuje R. Kuratow-Kuratowski, do końca XVII w. rozpowszechnione było przekonanie o przymusie występowania przez kobiety przed sądem w obecności męskiego opiekuna z racji „tzw. kruchości płci”. Interpretacja użytego w statucie wiślickim zwrotu fragilitas sexus była zdaniem autora błędna i należało go rozumieć jako przywilej, a nie przymus. Autor przytacza jednocześnie przykłady różnego rodzaju „zrzeczeń” (resignatio), także pokwitowań przyjęcia posagu, które to czynności mężatki dokonywały samodzielnie. Zob. R. Kuratow-Kuratowski, O zdolności cywilnej kobiet zamężnych w Małopolsce w wieku XIV , ,Studia nad Dziejami Prawa Polskiego Prywatnego” 1917, nr 15, s. 12 (39), 26-27 (54-55); P. Dąbkowski, Prawo prywatne..., t. I, s. 379; B. Lesiński, Stanowisko kobiety w polskim prawie ziemskim do połowy XV wieku, Wrocław 1956, s. 178.

${ }^{30}$ Przykładowo Ludwice Ryx z domu Melin przy składaniu oświadczenia asystował Mikołaj Melin (niestety w akcie nie wskazano rodzaju ani stopnia pokrewieństwa), MK 291, k. 513. 
praktykowano przydzielanie asystencji z urzędu. Odnotowano więc obecność przy sporządzaniu umów tych samych osób, np. Andrzeja Orłowskiego czy metrykanta Cypriana Sowińskiego, których każdorazowo za zgodą męża zapraszano do udziału w czynności (ad hunc actum de consensu mariti sui assumpti et rogati curatoris assistentia).

\subsection{Wzajemny charakter umowy}

Cechą charakterystyczną omawianej umowy była wzajemność (określana terminem reciproca $)^{31}$, polegająca na równoczesnym zobowiązaniu się każdej ze stron do przeniesienia własności swojego majątku na rzecz współmałżonka na wypadek wcześniejszej śmierci. Oba oświadczenia wyrażane były w jednym akcie. Darowizna taka wykazywała w tym zakresie podobieństwo do zawieranych na szerszą skalę wspomnianych zapisów dożywocia, wśród których w XVIII w. dominowały już zdecydowanie te o charakterze dwustronnym (advitalitas mutua).

\subsection{Przeniesienie wlasności}

Celem umowy było przeniesienie własności majątku na współmałżonka. W umowach zazwyczaj formułowano to w sposób generalny, bez szczegółowego wskazywania konkretnych dóbr, z zastrzeżeniem, że chodzi zarówno o te trzymane (zamieszkane) w chwili sporządzenia aktu, jak i te, które strony nabędą w przyszłości (nunc habitorum et in futurum habendorum) i które będą ich własnością w dniu śmierci. Przedmiotem darowizny były zarówno dobra ruchome, jak i nieruchome, dziedziczne i zastawne (omnia bona mobilia et immobilia, haereditaria et obligatoria). Zamieszczana uniwersalna klauzula przewidywała przeniesienie na małżonka pełni praw wyrażanych słowami: „cum omni jure dominio, proprietate, propinquitate, tituloque haereditario, parata possesionem cum plenaria potestate donandi, vendendi, commutandi, alienandi". Można jednak także znaleźć takie umowy, w których strony w załączonym aneksie precyzyjnie wskazywały dobra ziemskie będące przedmiotem darowizny. Na przykład małżonkowie Franciszek Ryx i Ludwika z domu Melin w 1794 r. zapisali sobie nawzajem w darowiźnie nieruchomości Wolkę Kozodawską, Jeżówkę i Chyliczki (Hyliczki) w ziemi warszawskiej oraz Jazgarzew w ziemi czerskiej ${ }^{32}$. Skutki umowy powstawały dopiero po śmierci pierwszego z małżonków (mortis causae). Wówczas następowało też przeniesienie własności na obdarowanego, podobnie jak w przypadku umowy dożywocia małżeńskiego (tu przenoszono jedynie prawo użytkowania), z którą w tym zakresie umowa darowizny wzajemnej wykazuje podobieństwo.

${ }^{31} \mathrm{~W}$ tekstach umów dla zaznaczenia charakteru czynności używany był również termin mutua, vicissim. K. Bukowska, pisząc o darowiźnie wzajemnej w prawie miejskim, używa terminu „świadczenie równoważne". Zob. K. Bukowska, Historia państwa i prawa..., t. II, s. 303.

${ }^{32}$ MK 289, k. 416; MK 291, k. 513. 


\subsection{Bezpotomność malżonków jako warunek zawarcia umowy darowizny}

Okolicznością, na którą powoływali się małżonkowie, była ich bezpotomność w chwili zawierania umowy donatio reciproca ${ }^{33}$. Wyraźna informacja o braku potomstwa w momencie jej podpisania pojawia się w większości tego rodzaju aktów („Quia illi prole desiderata carentes" ${ }^{34}$; „In casum aliquis periculi et imperata unius ex recognoscentibus sine desiderata prole mortis" ${ }^{35}$ ). Dodatkowo małżonkowie zastrzegali, że zawarte $\mathrm{w}$ umowie postanowienia wejdą w życie na wypadek bezdzietnej śmierci jednego z nich ${ }^{36}$. Uwagę zwraca również to, że umowy te w przeciwieństwie do zapisów dożywocia małżeńskiego sporządzanych najczęściej zaraz po ślubie ${ }^{37}$ zawierano raczej na późnym etapie małżeństwa, kiedy prawdopodobieństwo narodzin wspólnych dzieci było znikome lub wręcz niemożliwe. W kilku aktach czytamy, że małżonek zawierający umowę darowizny wzajemnej, choć cieszył się jasnością umysłu, niedomagał fizycznie ${ }^{38}$, co może sugerować jego podeszły wiek ${ }^{39}$.

${ }^{33}$ Możliwość dokonania darowizny dóbr, w tym dziedzicznych, przez osoby bezdzietne przewidywała już konstytucja z 1511 r.: ,Statuimus, quod steriles homines omnia bona sua haereditaria possint alienare iuxta suam voluntatem", VC, t. I, vol. 1, s. 246. Por. VL I, fol. 376. Brak dzieci jako okoliczność wpływająca na zakres testowania znana była także prawu miejskiemu - Wilkierz krakowski z 1550 r. pozwalał wówczas mężowi zapisać żonie w testamencie nieruchomości, z wyłączeniem dalszych krewnych. K. Bukowska, Historia państwa i prawa..., s. 310. Jak już wspomniano, również Zbiór Praw Sądowych Andrzeja Zamoyskiego wskazywał bezdzietność w „wieku przyzwoitym" jako warunek umożliwiający dokonanie darowizny nieruchomości (choć tylko nabytych). Zbiór Praw Sąowych... cz. II, art. XV § 8. Dotyczyło to również sytuacji, gdy małżonkowie przeżyli swoje dzieci, jak w przypadku Jakuba Fontany i Magdaleny z Barsthów (Barszczów?). Z testamentu mężczyzny z 1773 r. wynika, że stracił on zarówno córkę z pierwszego, jak i syna z drugiego małżeństwa ze wspominaną Magdaleną, MK 281, k. 10.

${ }^{34}$ MK 294, k. 98.

${ }^{35}$ MK 276, k. 167.

${ }^{36} \mathrm{Na}$ fakt ten zwraca uwagę M. Koczerska, Rodzina szlachecka..., s. 61.

${ }^{37}$ Sporządzenie wzajemnego zapisu dożywocia było częstym warunkiem zastrzeganym w umowie przedmałżeńskiej. Warunek taki znalazł się np. w kontrakcie zawartym 15 maja $1794 \mathrm{r}$. między Andrzejem i Zofią Piotrowskimi a przyszłym mężem ich córki Angeli - sędzią różańskim Andrzejem Ciemniewskim, MK 291, k. 565. Ślub odbył się 18 maja, a już 20 maja małżonkowie na wszystkich dobrach zapisali sobie wzajemnie dożywocie, MK 291, k. 569.

${ }^{38}$ W sporządzonym w 1794 r. akcie darowizny Ludwiki Ryx z domu Melin na rzecz jej męża Franciszka czytamy: „, chociaż na ciele słaba i na łóżku chorobą złożona, do ksiąg niniejszych dla zeznania transakcji przyjść nie mając mocy jednak umysłu najzdrowszego [...] zeznaje”, MK 291, k. 514. Podobnie w 1779 r., podczas sporządzania darowizny na rzecz Konstancji z Twarowskich jej mąż Jakub Łapiński był już, jak wynika z aktu, osobą podupadłą na zdrowiu (corpore quidem debilis), MK 295, k. 196.

${ }^{39} \mathrm{Z}$ kwestią zdrowia wiąże się również uboczne zagadnienie miejsca sporządzenia wpisu. Jak wynika z inskrypcji, swoje zeznanie Ludwika Ryx złożyła w domu swego męża, MK 291, k. 514. 


\subsection{Zasada wyłączenia krewnych od spadkobrania. \\ Obowiązek obdarowanego wypłaty rekompensaty na rzecz spadkobierców zmarłego małżonka}

Przeniesienie własności majątku na współmałżonka miało odbywać się z wyłączeniem najbliższych krewnych zmarłego ${ }^{40}$. Rozwiązanie to godziło $\mathrm{w}$ interes majątkowy członków rodziny, dlatego do obowiązków spoczywających na stronie, która przeżyła współmałżonka, zgodnie ze wspomnianą Rewizją nowomiejską należało dokonanie wypłaty pieniężnej rekompensaty dla najbliższych krewnych zmarłego, stanowiącej formę majątkowego zadośćuczynienia za wykluczenie ze spadkobrania. W zdecydowanej większości przypadków w umowach darowizny umieszczano takie zastrzeżenie: ,sed proximioribus tantum gradu summam [...] exsolvere" ${ }^{41}$. Kwota ta była zróżnicowana, zapewne w zależności od stopnia zamożności stron, stąd przykładowo: w 1793 r. kasztelan lubelski Piotr Potocki wraz z żoną Teresą z Karpiów zastrzegli dla najbliższych spadkobierców zmarłej strony po 10 tys. polskich złotych ${ }^{42}$, w 1777 r. małżonkowie Henryk i Adelgunda Konstancja Bastian umówili się na wypłatę krewnym 5 tys. zł ${ }^{43}$, w 1762 r. Mikołaj i Elżbieta Krosińscy ustalili kwotę 3 tys. zł ${ }^{44}$, zaś Michał i Regina Krajewscy w umowie z $1761 \mathrm{r}$. zobowiązali się do wypłacenia relatywnie niskiej sumy 100 polskich złotych ${ }^{45}$. W niektórych przypadkach umowa szczegółowo regulowała, jaka kwota pieniędzy przypadnie poszczególnym krewnym. W akcie daro-

${ }^{40}$ Znajdujemy tu podobieństwo z jednym ze zwodów prawa chełmińskiego: „Gdy jakiś człowiek pojmie żonę [...] mając swój majątek, a dzieci z nią mieć nie może, i tenże ma braci rodzonych i innych oprócz rodzonych (lecz) nie chce im nic dać ze swojego majątku i zdrowy na umyśle idzie ze swą żoną do sądu gajonego i tam [...] przekazuje swojej żonie, którą umiłował, cały swój majątek po swej śmierci, nic nie zostawiając braciom i innym krewnym. Wówczas (owa) niewiasta po śmierci swego męża obejmie bez jakichkolwiek przeszkód wszystko, co jej mąż przed sądem gajonym dał i zapisał". Nieznany spis prawa chetmińskiego z przełomu XIV-XV wieku, Księga II 9, oprac. Z. Rymaszewski, Łódź 1993.

${ }^{41}$ Rozwiązanie to wykazuje podobieństwo z instytucją ordynacji, z tą różnicą, że w przypadku ordynacji ordynat zobowiązany był do wypłaty periodycznego świadczenia w postaci stałej rocznej pensji. A. Mełeń, Ordynacje w dawnej Polsce, Lwów 1929, s. 56-57. W XIX w. ograniczenie w swobodnym rozporządzaniu majątkiem na wypadek śmierci na rzecz tzw. krewnych koniecznych (najbliższych krewnych zstępnych i wstępnych) przyjęto m.in. w Kodeksie Napoleona (tzw. system rezerwy). W przypadku pozostawienia przez spadkodawcę dzieci lub innych zstępnych mógł on zapisać współmałżonkowi w drodze testamentu jedynie $1 / 4$ majątku na własność i drugą 1/4 na użytkowanie bądź 1/2 całego majątku na użytkowanie. Zob. Kodex Napoleona, Xiag trzy, Warszawa 1810, art. 1094; J. Bieda, Testament - prawo a praktyka Królestwa Polskiego. W świetle akt notariuszy zgierskich w latach 1826-1875, Łódź 2013, s. 117.

${ }^{42}$ MK 291, k. 478.

${ }^{43}$ MK 294, k. 98.

${ }^{44}$ MK 277, k. 61 v.

${ }^{45}$ MK 276, k. 167 v. 
wizny Karola Lagenie i jego żony Anny z Kostrzewskich z 1772 r. strony wzajemnie zobowiązały się do wypłaty odpowiednio: rodzeństwu Karola: bratu Józefowi i siostrze Annie Fryderyce Rudzkiej po 500 zł oraz bratanicy Marcjannie Reverdil 2 tys. zł, zaś bratu Anny, Jakubowi -3 tys. $z^{46}$.

Przewidziana na rzecz najbliższych kwota mogła być zapisana w formie gotowizny, a także roszczenia pieniężnego przysługującego darczyńcy z tytułu wierzytelności. W darowiźnie sporządzonej przez Jakuba Łapińskiego na rzecz Konstancji z Twarowskich w 1779 r. mąż zastrzegł dla swojego bratanka ${ }^{47}$ Jana Łapińskiego sumę 3037 zł w postaci długu należnego od Kazimierza i Anny Kraśnickich, a także 8 tys. zł z ogólnej sumy 20 tys. zł zobowiązania łowczego sochaczewskiego Fabiana Cholewskiego. Reszta (12 tys. zł) miała zostać wypłacona w równych częściach między pozostałych sukcesorów: Jana, Józefa i Stanisława Łapińskich - braci Jakuba oraz Laurenta Płońskiego, Franciszka Zdrodowskiego, a także Marcina i Andrzeja Łapińskich ${ }^{48}$.

Na marginesie warto dodać, że wspomniane kwoty wyrażano również w innej monecie, takiej jak węgierski złoty floren ${ }^{49}$, a nawet tynf ${ }^{50}$. Niekiedy wskazywano też okres, w którym wypłata miała nastąpić, np. w ciągu sześciu miesięcy od dnia śmierci darczyńcy ${ }^{51}$.

Nie zawsze jednak wskazywano w umowie kwotę pieniężną. W akcie darowizny Karola Franciszka Susson i Franciszki z Melinów z 1794 r. ustalono, że spadkobiercy wcześniej zmarłego małżonka otrzymają czwartą część z tej połowy wspólnego majątku małżonków, która zostanie po zmarłym, a oszacuje się ją na podstawie sporządzonego $\mathrm{w}$ chwili śmierci pierwszego z małżonków urzędowego inwentarza ${ }^{52}$. W umowie tej zarazem zapisano: „, przypadku zaś żadnego z krewnych w stopniu prawem przepisanym po zmarłej głowie nieznajdowania się pozostały w życiu mąż lub małżonka cały i nierozdzielny majątek pozostały,

${ }^{46}$ MK 280, k. 174.

${ }^{47}$ Użyty w tekście termin filiaster jest wieloznaczny. J. Sondel podaje wyłącznie cztery jego znaczenia i tłumaczy to słowo jako pasierb, zięć, bastard lub wnuk urodzony z córki. Stownik łacińsko-polski dla prawników i historyków, Kraków 2005, s. 383. A. Szymczakowa stwierdza natomiast, że najczęściej termin filiaster oznaczał synowca, czyli syna brata. Nazewnictwo stosunków rodzinnych w świetle praktyki sądów sieradzkich w 15. wieku, „Studia z Dziejów Państwa i Prawa Polskiego" 1995, t. II, s. 101. W omawianym przypadku, mając na względzie nazwisko Jana, można przyjąć to ostatnie thumaczenie.

${ }^{48}$ MK 295, k. 195 v.

49 Karol Schmidt i Anna Fryz w darowiźnie z 1752 r. umówili się na przekazanie najbliższym krewnym kwoty 200 florenów węgierskich, MK 265, k. 213.

${ }^{50} \mathrm{Na}$ takie rozwiązanie zdecydowali się w 1760 r. Joachim Rottermund i Anna Zofia z Małkowskich, ustalając wysokość wypłaty dla krewnych na 3 tys. tynfów, MK 276, k. 54v.

${ }^{51}$ MK 265, k. 213.

52 MK 291, k. 572. 
tytułem najzupełniejszej własności, trzymać, posiadać i nim jako własnym zarządzać według woli swojej będzie" 53 .

Jeszcze inne rozwiązanie przyjęto w darowiźnie sporządzonej w 1770 r. przez Jakuba Fontanę na rzecz żony Magdaleny ${ }^{54}$. Suma, którą w razie wcześniejszej śmierci męża wdowa powinna przekazać krewnym zmarłego, miała zostać określona w testamencie Jakuba ${ }^{55}$.

\subsection{Zobowiązanie obdarowanego do pokrycia kosztów pochówku darczyńcy}

Ponadto do obowiązku owdowiałego małżonka należało, zgodnie z umieszczonym w akcie zobowiązaniem, zorganizowanie zmarłemu przyzwoitego pochówku (decens sepultura) i odmówienie modlitwy (wstawienia się) za jego duszę (suffragia pro anima).

\subsection{Utrata mocy obowiązującej umowy w przypadku narodzin dziecka}

Umowa darowizny zawierana była pod warunkiem rozwiązującym, co oznaczało uchylenie jej w razie zaistnienia określonego zdarzenia. We wszystkich umowach donatio reciproca umieszczano na końcu klauzulę, zgodnie z którą umowa miała utracić swoją moc bez potrzeby unieważnienia jej w drodze odrębnego oświadczenia woli w przypadku narodzin dziecka ${ }^{56}$.

\subsection{Umowy złożone}

Konstrukcja niektórych umów miała bardziej złożony charakter. Przykładem jest akt podpisany w 1780 r. przez nieposiadających wspólnych dzieci małżonków Antoniego i Angelę Lucińskich. Wynikało z niego, że ich jedynym wspólnym dorobkowym majątkiem są rzeczy ruchome i gotówka w kwocie 180 tys. zł. Sumę tę podzielono na trzy równe części. Po śmierci jednego z małżonków 60 tys. zł miało

53 Ibidem.

${ }^{54} \mathrm{O}$ darowiznach jednostronnych szerzej w dalszej części artykułu.

55 MK 279, k. 470.

${ }^{56}$ „Sin autem prole desiderata illos Deus omnipotens in futurum beare velit, atque proles se recognescentes seu alterutrum supervixerit, praesens reciproca donates superveniente prole ipso facto absque alia cassatione nulla erit, sed juxta praescriptumlegis uterque conjunx superstes se gerere debebit'. Warto dodać, że odmienne stanowisko zajęli autorzy Kodeksu Napoleona. Owszem, zakładał on odwołanie darowizny ex lege w przypadku przyjścia na świat dziecka darczyńcy (art. 960), jednak przypadek ten nie dotyczył darowizny między samymi małżonkami (art. 1096), co tłumaczono bezzasadnością zwracania majątku darczyńcy, skoro dziecko miało w przyszłości otrzymać ów majątek po śmierci obdarowanego współmałżonka. Zob. A. Okolski, Zasady prawa cywilnego obowiązującego w Królestwie Polskiem, Warszawa 1885, s. 396; M. Planiol, Podręcznik prawa cywilnego (o darowiznach i testamentach), z francuskiego przełożył i przypisami opatrzył Adam Słomiński, Warszawa 1922, s. 272-273. 
zostać bezpośrednio przekazane na własność drugiego. Kolejne 60 tys. zł przeznaczono jako dożywocie (które zobowiązano się ustanowić w formie osobnego zapisu $^{57}$ ), z zastrzeżeniem, że „na tej sumie, gdyby z niej sposobem darowizny lub jedno drugiemu lub komużkolwiek zdało nam się zapisać, dać, darować, zupełną sobie w tym wolność ostrzegamy i zachowujemy". Wreszcie trzecią część sumy miała otrzymać w chwili zamążpójścia Marianna - córka Angeli (!) z jej pierwszego małżeństwa z Jackiem Sapińskim, z zastrzeżeniem zatrzymania tej sumy przez małżonków Lucińskich (po 30 tys. zł na głowę) w przypadku wcześniejszej śmierci Marianny. W razie powiększenia masy majątkowej ewentualną dodatkową kwotę strony zobowiązywały się podzielić równo między siebie. Natomiast odnośnie do rzeczy ruchomych na zasadach darowizny wzajemnej miały zostać z prawem własności przekazane stronie pozostałej przy życiu. Kwotę przeznaczoną na wypłatę najbliższym krewnym ustalono na 2 tys. $z^{58}$. Jak widać na tym przykładzie, małżonkowie mogli kształtować swoje zeznania w sposób dowolny, łącząc zapis dożywocia i darowizny wedle uznania, w granicach dopuszczanych przez prawo.

\subsection{Darowizny rzeczy ruchomych}

Warto nadmienić, że oprócz przedstawionych umów typu donatio reciproca, obejmujących wszystkie rodzaje dóbr, w aktach Metryki Koronnej znaleźć można również darowizny wzajemne obejmujące wyłącznie rzeczy ruchome, jak w umowach z 1789 r.: łowczyca nowogrodzkiego Mikołaja Wolskiego i Angeli z Kownackich ${ }^{59}$ oraz Józefa Rogalińskiego i Konstancji z Denhoffów ${ }^{60}$. Nie były one obostrzone dodatkowymi warunkami. W obu aktach opisywanych w Metryce pt. „Donant sibi mutuo mobilia” nie ma informacji o bezdzietności małżonków czy o poleceniach wypłaty określonej sumy pieniędzy na rzecz krewnych zmarłego. Formularz wykorzystany do tego rodzaju umów zawierał natomiast uniwersalny katalog dóbr ruchomych, które były objęte w darowiźnie - od złota, srebra i klejnotów począwszy, przez kobierce i dywany, na zwierzętach hodowlanych, płodach rolnych i sprzęcie domowym skończywszy ${ }^{61}$.

${ }^{57}$ Zapis taki sporządzono tego samego dnia, MK 284, k. 47v.

${ }^{58}$ MK 284, k. 45.

${ }^{59}$ MK 302, k. 54.

${ }^{60}$ MK 302, k. 109.

${ }^{61}$ „Auro, argento formato et non formato, clenodiis, margaritiis et lapidibus pretiosis, aere, cupro, stanno, vestibus, vestimentis, tapetibus, equis, equireis, ovibus, pecoribus, pecudibus, frumentis, trituratis et non trituratis totaq et integra supellectili domestica". Bardzo podobny katalog znajdziemy również w większości formularzy zapisów dożywocia. 


\section{Darowizny jednostronne}

Niezależnie od darowizn wzajemnych w aktach Metryki Koronnej odnotowano 12 darowizn jednostronnych, na mocy których oświadczenie o przekazaniu majątku na wypadek swojej śmierci składał tylko jeden z małżonków. Także w tych przypadkach wskazywano na brak wspólnego potomstwa i obowiązek strony obdarowanej do wypłaty określonej sumy na rzecz spadkobierców darczyńcy. Zapisy takie sporządzili m.in.: w 1782 r. Daniel Belgram, starosta malczowski, na rzecz żony Marianny z Paszkowskich (darowując jej na wypadek swojej śmierci nie tylko dobra ziemskie Równo w województwie ruskim, ale także połowę „domu murowanego" w Warszawie) $)^{62}$, w 1768 r. Franciszka ze Śliwińskich na rzecz męża Jana Franciszka Cywińskiego ${ }^{63}$ czy w 1781 r. Zofia z Krajewskich na rzecz męża Franciszka Wysockiego ${ }^{64}$. Przynajmniej w niektórych przypadkach jednostronna darowizna poczyniona na rzecz małżonka była odwzajemnieniem takiego samego aktu sporządzonego wcześniej. Taka sytuacja miała miejsce u wspomnianego wcześniej małżeństwa Franciszka i Ludwiki Ryx, którzy odpowiednio w 1791 i 1794 r. zapisali sobie w darowiźnie wszystkie dobra ruchome i nieruchome, przy czym w oświadczeniu kobiety znalazło się stwierdzenie, że jej decyzja wynika „,z przyczyny darowanej sobie w czasie słabości tegoż urodzonego męża swego przed księgami niniejszymi dnia 2 listopada 1791 roku dóbr prawu miejskiemu podległych połowy”65. W tym przypadku darowizna Ludwiki Ryx, choć sporządzona w osobnym akcie, była czynnikiem tworzącym między małżonkami relację darowizny wzajemnej. Powyższe przykłady dowodzą, że darowizny jednostronne sporządzali zarówno mężowie, jak i żony, a z odnotowanych przypadków wynika, iż w siedmiu darczyńcami byli mężczyźni, w pięciu kobiety - można więc założyć, że powyższe statystyki kształtują się na zbliżonym poziomie.

\section{PODSUMOWANIE}

Rozwój małżeńskich stosunków majątkowych w I Rzeczypospolitej stał pod znakiem ścierania się dwóch koncepcji: rozdzielności i wspólności majątkowej. Pierwsza z nich zakładała potrzebę zachowania dóbr w obrębie rodu, co wiązało się z wyłączeniem współmałżonka przy podziale schedy spadkowej. Druga zmierzała do zabezpieczenia interesu majątkowego żony (męża) z jednoczesnym ograniczeniem praw krewnych spadkodawcy. Zauważalna od XV-XVI w. tendencja

\footnotetext{
${ }^{62}$ MK 291, k. 409, 412.

${ }^{63}$ MK 278, k. 554.

${ }^{64}$ MK 284, k. 107.

${ }^{65}$ MK 289, k. 416; MK 291, k. 513.
} 
do wzmacniania pozycji majątkowej małżonka (głównie przez zapisy dożywocia małżeńskiego) znalazła również odzwierciedlenie w postaci umów darowizny na wypadek śmierci. Szczególnie donatio reciproca stanowiła dla małżonków atrakcyjne rozwiązanie, pozwalające na realizację celu, jakim było wzajemne zabezpieczenie majątkowe małżonków - niemożliwe do osiągnięcia w drodze testamentu. Uwagę zwraca praktyczny walor darowizny wzajemnej. Umożliwiała ona małżonkom oprócz dwóch niezależnych aktów złożenie odpowiednich oświadczeń $\mathrm{w}$ jednym akcie ${ }^{66}$, podczas gdy polskie prawo ziemskie nie dopuszczało tzw. testamentu wzajemnego ${ }^{67}$. Jednocześnie dla sporządzenia aktu darowizny wzajemnej nie wymagano szczególnego, zastrzeżonej dla testamentu warunku: obecności trzech świadków ${ }^{68}$.

Oszacowanie skali sporządzania darowizn na podstawie jednego źródła, jakim jest Metryka Koronna, nie należy do zadań łatwych. W badanym okresie blisko stu lat odnotowano 29 aktów różnego typu darowizn małżeńskich na wypadek śmierci. Na ogólną ich liczbę mogą rzutować dwa czynniki. Przede wszystkim trzeba mieć na uwadze fakt sporządzania zapisów przez małżeństwa bezdzietne, umowy nie mogły mieć zatem powszechnego charakteru. Druga kwestia to szczególny charakter Metryki, do której swoje zeznania składali obywatele osiadli w różnych ziemiach i województwach Rzeczypospolitej, co nadaje badaniom walor uniwersalny. Ponadto podstawowym i często jedynym miejscem zgłaszania umów były kancelarie ziemskie. Stąd dopiero gruntowna kwerenda akt ziemskich pozwoliłaby ocenić, choćby w przybliżeniu, ich ogólną liczbę.

Kolejne spostrzeżenie dotyczy lat, w których rejestrowano umowy darowizn małżeńskich. Można zauważyć, że z upływem lat akty te pojawiają się w Metryce Koronnej częściej. Począwszy od 1700 r., do połowy XVIII w. nie stwierdzono żadnej umowy tego rodzaju. Pierwsza odnotowana darowizna małżeńska na wypadek śmierci została oblatowana w księgach Metryki w 1752 r. (umowę zawarto w 1748 r.). W latach 50. było ich ogółem 4, w 60. - 4, w 70. - 6, w 80. - 10, a w ostatnich czterech latach funkcjonowania Metryki - 5. Trudno jednoznacznie ocenić, czy ten niewielki, acz zauważalny przyrost był efektem większego zainteresowania sporządzaniem tego typu aktów, czy raczej zmiany charakteru

${ }^{66}$ Instytucję darowizny wzajemnej między małżonkami znał późniejszy Kodeks Napoleona. Zakładał on jednak obowiązek sporządzenia takiej darowizny w dwóch oddzielnych aktach. M. Planiol, Podręcznik prawa cywilnego..., s. 274-277.

${ }^{67}$ Testament wzajemny, znany od XVI w. prawu miejskiemu w Niemczech, umożliwiał dwóm osobom ustanowienie się wzajemnie spadkobiercami. S. Płaza, Historia prawa..., cz. I, s. 303. O powszechnym sporządzaniu przez małżonków testamentów wzajemnych w miastach na przykładzie Gdańska pisze E. Kizik, Zabezpieczenie majątkowe wdów w Gdańsku w XVII-XVIII wieku, „Kwartalnik Historii Kultury Materialnej” 2010, t. LVIII, s. 88-89.

${ }^{68}$ P. Dąbkowski, Prawo prywatne..., t. II, s. 90. 
księgi wpisów Metryki Koronnej, do której coraz chętniej zgłaszano się w celu oblatowania takich umów.

Małżeńskie prawo majątkowe okresu I Rzeczypospolitej, mimo pojawiających się ostatnio prac poświęconych tej problematyce ${ }^{69}$, wciąż pozostaje, zwłaszcza dla historyków prawa, obszarem oczekującym na dalsze gruntowne badania. Należy przy tym zwrócić uwagę na umowę darowizny małżeńskiej na wypadek śmierci - instytucji, która, jak wynika z materiałów źródłowych, znalazła zastosowanie $\mathrm{w}$ praktyce, nie tylko w prawie miejskim. Przyczynkowy charakter powyższej pracy może więc być dobrym punktem wyjścia do szerszych badań $\mathrm{w}$ tym zakresie.

\title{
MARITAL GIFTS CAUSA MORTIS IN THE $18^{\text {TH }}$ CENTURY IN LIGHT OF THE METRICA REGNI RECORDS
}

\begin{abstract}
Gifts causa mortis between spouses, even though it was an institution regulated by Chełmno law, started to gradually gain popularity among the nobility in the $18^{\text {th }}$ century. It constituted an attractive alternative to the commonly employed life estate. Even though it provided economical security for life tenants, it did not transfer ownership rights to them and it also introduced a number of restrictions, including the prohibition of alienation of the property described in a deed. The gift causa mortis was a more advantageous solution for spouses. Nevertheless, they only could have signed such an agreement if they had no offspring together. The right of ownership was transferred in accordance with the contract. Contrary to the life estate, gifts did not result in a suspension of heirs' rights but it excluded them from inheriting. It was the duty of the party receiving the gift to pay out recompense to the closest relatives of the deceased only. It was most frequently in the form of a sum of money stipulated in the contract.
\end{abstract}

Keywords: gift causa mortis, life estate, marital property agreements, Chełmno law, widow, donatio reciproca, Metrica Regni

${ }^{69} \mathrm{Na}$ uwagę zasługują dwie wydane ostatnio monografie A. Penkały, Panieńskie ochędóstwo. Kwestie posagowe $i$ wienne $w$ matżeństwach szlachty województwa krakowskiego $w$ czasach saskich, Kraków 2016; Przeciw prawu, tradycji i obyczajowi. Sprawy procesowe szlacheckich matżeństw w księgach sądów grodzkich z terenu województwa krakowskiego w czasach saskich, Kraków 2017. 